\title{
MOBILIZATION OF ENDOGENOUS GLYCOGEN AND TREHALOSE OF INDUSTRIAL YEASTS
}

\author{
Silene Cristina de Lima Paulillo ${ }^{1 *}$; Fumio Yokoya ${ }^{2}$ Luiz Carlos Basso $^{1}$ \\ ${ }^{1}$ Departamento de Ciências Biológicas, Escola Superior de Agricultura Luiz de Queiroz, USP, Piracicaba, SP, Brasil. \\ ${ }^{2}$ Fundação André Tosello, Campinas, SP, Brasil.
}

Submitted: July 10, 2002; Returned to Authors: May 13, 2003; Approved: September 08, 2003

\begin{abstract}
The fermentation of yeast reserve carbohydrates, glycogen and trehalose is a procedure to increase protein level of yeast cells and improve ethanol production. This work studied on the degradation kinetics of glycogen and trehalose carried out with two industrial strains of Saccharomyces cerevisiae (PE-2 and SA-1) and the effect of different temperatures $\left(38^{\circ}, 40^{\circ}, 42^{\circ}\right.$ and $\left.44^{\circ} \mathrm{C}\right)$ on degradation rate. Endogenous fermentation was carried out in a yeast suspension at $20 \%$ (w/v) based on wet weight, suspended in fermented media with 3.0 to $4.5 \%(\mathrm{v} / \mathrm{v})$ of ethanol. The degradation of the carbohydrate reserves at $40^{\circ} \mathrm{C}$ followed first-order kinetics, showing that its rate is mainly dependent on the carbohydrate concentration in the cell. The degradation rate (k) ranged from 0.0387 to $0.0746 \mathrm{~h}^{-1}$. Analyzing other parameters at $40^{\circ} \mathrm{C}$, it was observed that viability and dry and wet yeast biomass were reduced while cell protein, ethanol, glycerol and nitrogen in the medium increased. Glycogen and trehalose degradation at different temperatures $\left(38^{\circ}, 40^{\circ}, 42^{\circ}\right.$ e $\left.44^{\circ} \mathrm{C}\right)$ showed that at $38^{\circ} \mathrm{C}$ the degradation rate was slow and from $42^{\circ} \mathrm{C}$ on the degradation of glycogen stopped after few hours of incubation. Thus, from a practical point of view, the best incubation temperature is around $40^{\circ} \mathrm{C}$. The application of the Arrhenius equation showed that activation energy from $40^{\circ}$ to $42^{\circ} \mathrm{C}$ was 165.90 and $107.94 \mathrm{kcal}^{\circ} \mathrm{K}^{-1}$. $\mathrm{mol}^{-1}$ for trehalose and glycogen respectively for PE-2 strain, and 190.64 and $149.87 \mathrm{kcal}^{\circ} \mathrm{K}^{-1} \cdot \mathrm{mol}^{-1}$ respectively for SA1 strain.
\end{abstract}

Key words: Saccharomyces cerevisiae, glycogen, trehalose, yeast, fermentation.

\section{INTRODUCTION}

In many parts of the world, several industrial products and by-products have become seasonally available. Some are polluting materials but others could be valuable nutrients, and are broadly known as non-conventional products (13). Various microorganisms, such as bacteria, yeasts, fungi and algae have been included among non-conventional products. They are important sources of proteins, vitamins and minerals, yeast cells being the most important for human and animal consumption (12). Therefore, it may be noted that yeast is considered the most studied eukaryotic organism, because of the economic relevance of the biotechnological processes involved.

Since the fuel alcohol program was established in Brazil, a large amount of yeast cells have been available as a by-product, which in many instances could become a burdensome pollution problem. Assuming an average current production of 14 billion liters of ethanol per year in Brazil, the total amount of dry yeast cells could reach 11,200,000 t/year, if the figure of $80 \mathrm{~kg}$ of yeast per $\mathrm{m}^{3}$ of ethanol is taken into consideration (5). Even if a conservative value of $50 \mathrm{~kg} / \mathrm{m}^{3}$ is assumed, the amount of dry yeast cells available would be 7,100,000 t/year, which is a respectable figure.

Exponentially growing yeast cells have rather small carbohydrate reserves, but at the end of the growing cycle they may accumulate as much as $23 \%$ on dry weight basis (10). Yeasts are known to store energy in the form of the carbohydrate glycogen (7). The carbohydrate trehalose is also considered as an energy reservoir (9), but its major function is attributed to cell protection against stressful environmental factors $(7,21)$. The effect of cell membrane protection during dehydration-

*Corresponding author: Mailing Address: Av. Pádua Dias, 11. 13418-900, Piracicaba, SP, Brasil. Tel.: (+5519) 3429-4169. E-mail: limasc@ hotmail.com 
hydration and freezing-thawing was observed, and some interaction between trehalose and cell membrane phospholipids was suggested $(6,17)$.

Whatever the cause, the surplus yeast cells from fuel alcohol plants usually have $30 \%$ to $35 \%$ protein on a dry weight basis and a considerable amount of carbohydrate reserves (trehalose and glycogen). The commercial value of the product would significantly improve provided thatthe protein content is raised to $40 \%$, or preferably to over $45 \%$. This could be achieved if these carbohydrate reserves were reduced by a process known as endogenous fermentation (1), which metabolizes carbohydrates, glycogen and trehalose through a glycolytic flux. This process occurs under yeast stress conditions. This paper shows the variation of yeast cell component and surrounding media data during endogenous fermentations performed at different temperature rangingfrom $38^{\circ}$ to $44^{\circ} \mathrm{C}$.

\section{MATERIALS AND METHODS}

\section{Microorganisms and growth conditions}

Two industrial strains of Saccharomyces cerevisiae were used: PE-2 isolated from Usina da Pedra sugar mill (Serrana, SP, Brazil) during the 1993/94 crushing season, and SA-1 isolated from Usina Santa Adelia sugar mill (Jaboticabal, SP, Brazil) during the 1989/90 crushing season, both in Brazil. They were kindly supplied by Culture Collection of Fermentec S/C Ltda (Piracicaba, SP, Brazil).

Cultures were grown in $100 \mathrm{~mL}$ YEPD broth, $\mathrm{pH}$ 6.5-7.0 at $32^{\circ} \mathrm{C}$. YEPD had the following composition: yeast extract $10 \mathrm{~g}$; peptone $10 \mathrm{~g}$; dextrose $20 \mathrm{~g}$ and distilled water $1 \mathrm{~L}$. After growth, the yeast suspension was transferred to a propagation medium with $6 \%$ total reducing sugars (TRS) from sugar cane molasses supplemented with $\mathrm{K}_{2} \mathrm{HPO}_{4}(5 \mathrm{mM}),\left(\mathrm{NH}_{4}\right)_{2} \mathrm{SO}_{4}(5 \mathrm{mM})$, urea (5 mM), $\mathrm{MgSO}_{4} .7 \mathrm{H}_{2} \mathrm{O}(2 \mathrm{mM}), \mathrm{ZnSO}_{4} .7 \mathrm{H}_{2} \mathrm{O}(0.1 \mathrm{mM})$, $\mathrm{MnSO}_{4} \cdot \mathrm{H}_{2} \mathrm{O}(0.1 \mathrm{mM})$, linoleic acid $(1.0 \mathrm{~mL} / \mathrm{L})$ in distilled water. The medium was sterilized at $120^{\circ} \mathrm{C} / 20 \mathrm{~min}$. After inoculation, the cultures were incubated at $32^{\circ} \mathrm{C}$ for ca $48 \mathrm{~h}$ with occasional stirring. After growth the cultures were left standing at $5^{\circ} \mathrm{C}$ for $48 \mathrm{~h}$ for cell sedimentation. After sedimentation this culture was separated from the fermented media and used in the next step: a pre-fermentation with $15 \%$ TRS.

\section{Yeast cell conditioning}

Yeast (10 g fresh weigh per $100 \mathrm{~mL}$ substrate) was submitted to fermentation at $32^{\circ} \mathrm{C}$, usinga mixture of sugar cane juice and molasses with $15 \%$ TRS (w/v) as a substrate (30\% of sugar from molasses). After fermentation yeast was collected through centrifugation ( $800 \mathrm{x} / \mathrm{g}$ for $20 \mathrm{~min}$ ). Ethanol in fermented media and yeast viability were analyzed. This $15 \%$ TRS fermentation allows trehalose and glycogen to accumulate in the yeast cell, preparing the yeast for the next step, which is the fermentation of carbohydrate reserves.

\section{Fermentation of carbohydrate reserves}

This test was carried out in a yeast suspension with ca. $20 \%$ $(\mathrm{w} / \mathrm{v})$ wet weight in the fermented media with 3.0 to $4.5 \%(\mathrm{v} / \mathrm{v})$ ethanol and incubated at different temperatures. Thus there was no increase of nutrients. Samples were collected at different intervals and cell viability, biomass, glycogen, trehalose, and total nitrogen in the yeast biomass were analyzed. Glycerol, nitrogen and ethanol in the surrounding media were analyzed.

The data variability was performed by means of the Analysis of Variance, by the F Test. The data were adjusted to the equation models according to the best coefficient values obtained. The analyses were processed by using the program "JMP-SAS" (System Analysis Statistic).

\section{Analytical methods}

Cell viability (\% viable cells) was measured by erythrosine red staining and observed through an optical microscope. Ethanol content was measured by distilling $25 \mathrm{~mL}$ of the fermented media in a Kjeldahl micro-distiller and submitted to digital densimetry (Anton-Paar DMA-48 densimeter).

Cell biomass (wet weight) was obtained by centrifuging $10 \mathrm{~mL}$ of sample $(800 \times \mathrm{g} / 5 \mathrm{~min})$. Dry weight was maintained at $100-105^{\circ} \mathrm{C}$ until it reached a constant weight. Nitrogen content was determined by the Kjeldahl method and converted into protein (N\% x 6.25). Glycerol content in centrifuged broth was determinedthrough high performance liquid chromatography (HPLC) (8).

Glycogen was determined through Becker's method adapted by Rocha-Leão et al. (19). The sample (60 mg yeast; wet basis) was first digested with sodium carbonate $0.25 \mathrm{M}$ at $100^{\circ} \mathrm{C}$ for 90 min. and then hydrolyzed at $37^{\circ} \mathrm{C}, \mathrm{pH} 4.8$, with amyloglucosidase (EC 3.2.1.3) of Rhizopus sp. (Sigma No. A-7255). The amount of glucose formed was determined through the glucose oxydase/ peroxydase method $\left(30^{\circ} \mathrm{C}\right.$ for $\left.40 \mathrm{~min}, \mathrm{pH}=6.0\right)$. The color reaction with ortho-dianisidyne was measured at wavelength $525 \mathrm{~nm}$, and the result was shown as $\mathrm{g}$ of glycogen/ $100 \mathrm{~g}$ dry yeast matter.

Trehalose was extracted from $60 \mathrm{mg}$ yeast (wet basis) using cold $0.5 \mathrm{M}$ trichloroacetic acid according to Trevelyan and Harrison $(23,24)$ and then determined through the anthrone reaction (3). The colored product was detected at wavelength $620 \mathrm{~nm}$ and the results were presented as $\mathrm{g}$ of trehalose/ 100g of dry matter.

\section{RESULTS AND DISCUSSION}

\section{Kinetics of glycogen and trehalose degradation}

In order to analyze the kinetics of carbohydrates degradation, original data of carbohydrate concentration were transformed into logarithms (10 basis) (Fig. 1). It shows the degradation of trehalose and glycogen in S. cerevisiae (PE-2 and SA-1) at $40^{\circ} \mathrm{C}$. If the carbohydrate content log (trehalose and glycogen) were plotted, maintaining the incubation time, a straight line would be 


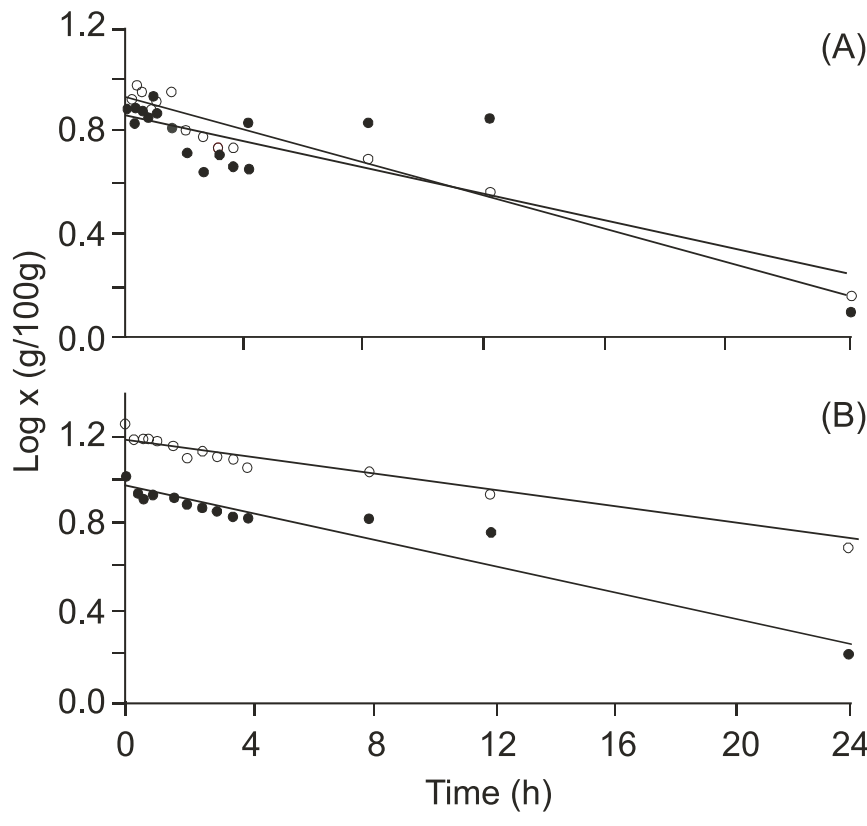

Figure 1. Trehalose $(O)$ and glycogen $(O)$ contents in yeast cells treated at $40^{\circ} \mathrm{C}$. (A) S. cerevisiae PE-2 and (B) S. cerevisiae SA-1.

observed (Fig. 1), indicating that degradation is a function of carbohydrate concentration and follows a first kinetics order. Using this approach the carbohydrate constant degradation rate (k) was determined by the straight line of the Fig. 1 as shown in Table 1 . These data indicated that about $70 \%$ of carbohydrates were removed from the cells within 2 days of incubation. This study shows that the kinetics of degradation follow the equation of the first order, indicating that speed is an exclusive function of the concentration of carbohydrates present in the cell, therefore there would be different rates of degradation of these carbohydrates according to their concentrations inside the cells, which justifies the differences found in the values in Tables 1 and 3 .

Since the commercial value of dry yeast depends on its protein content, it is highly desirable for this figure to be above $40 \%$ on a dry weight basis. Normal dry yeast obtained in fuel alcohol plants, without any treatment, contains 33 to $35 \%$ proteins, but they could be increased by means of an endogenous fermentation process as shown by Amorim and Basso (1). The mechanism involved in this fermentation process and some data about the rate of glycogen and trehalose degradation will help with finding the proper temperature and treatment time required for better efficiency.

\section{Other parameters at $40^{\circ} \mathrm{C}$}

The variations of several yeast suspension parameters during incubation at $40^{\circ} \mathrm{C}$ are shown in Table 2 . They could be satisfactorily described by a $2^{\text {nd }}$ order equation, except for yeast
Table 1. Degradation rate constants $\left(\mathrm{k}=\mathrm{h}^{-1}\right)$ for trehalose and glycogen at $40^{\circ} \mathrm{C}$.

\begin{tabular}{lcc}
\hline & Trehalose & Glycogen \\
\hline $\begin{array}{l}\text { Saccharomyces cerevisiae } \\
\text { PE-2 }\end{array}$ & $0.0649(35.5) *$ & $0.0746(30.9)$ \\
Saccharomyces cerevisiae & $0.0649(35.5)$ & $0.0387(59.5)$ \\
SA-1 & & \\
* Values between brackets indicate the time, in hours, necessary \\
to get 90\% of degradation.
\end{tabular}

dry weight and carbohydrate content (trehalose and glycogen). A reduction in the following parameters was noticed during the treatment: viability; dry and wet yeast weight; carbohydrate content (trehalose and glycogen). Conversely, the following parameters showed an increase: nitrogen content in the yeast and the medium, and ethanol and glycerol in the medium. Table 2 shows these data after $24 \mathrm{~h}$ of treatment in comparison to the original suspension (zero hour - treatment).

The protein content increased from $35.3 \%$ to $44.2 \%$ and from $44.3 \%$ to $51.8 \%$, for PE-2 and SA-1 respectively, which resulted in increments of $25 \%$ and $17 \%$ respectively. This increase was mainly due to the degradation of carbohydrates (trehalose and glycogen) since their levels fell from $15.6 \%$ to $0.0 \%$ and $24.8 \%$ to $7.4 \%$, for PE-2 and SA-1 respectively. The cell dry weight reduction was only $1.94 \%$ and $1.56 \%$, respectively, for PE-2 and SA-1. The release of nitrogen from yeast cells to the medium was only $1.18 \%$ and $2.83 \%$, for PE-2 and SA-1 respectively, and most of the protein was maintained in the yeast cells. One must consider that these data were obtained from laboratory grown yeast. In an actual industrial equation the overall protein content is usually lower due to the impurities normally found in industrial must. Hence, $33-35 \%$ of protein content must be considered normal and an increment of $15 \%$ to $20 \%$ was expected with this treatment.

Most of the carbohydrates were transformed into ethanol during the endogenous fermentation (unplublished data), which could be an additional advantage to the alcohol industry. In this paper, this conversion was incomplete and rather variable: $21.0 \%$ and $41.0 \%$, respectively, for PE-2 and SA-1. In an ideal fermentation these figures should be above $45 \%$ (2) although glycerol, organic acids and other metabolic by-products must be produced during the process.

\section{Glycogen and trehalose degradation at different temperatures}

Table 3 shows the trehalose and glycogen constant degradation rate of PE-2 and SA-1 strains submitted to endogenous fermentation at temperatures of $38^{\circ} \mathrm{C}, 40^{\circ} \mathrm{C}, 42^{\circ} \mathrm{C}$ and $44^{\circ} \mathrm{C}$. The temperature rise from $38^{\circ} \mathrm{C}$ to $40^{\circ} \mathrm{C}$ caused a small increase in the degradation rate. However, a remarkable variation 
Table 2. Variation in different parameters during endogenous fermentation at $40^{\circ} \mathrm{C}$ for $24 \mathrm{~h}$.

\begin{tabular}{llccc}
\hline \multicolumn{1}{c}{ Parameter } & \multicolumn{1}{c}{ Units } & $0 \mathrm{~h}$ & $24 \mathrm{~h}$ & Variation \\
\hline PE-2 & \multicolumn{1}{c}{} & & \\
\hline Yeast protein & $\mathrm{g} / 100 \mathrm{~g}$ dry wt. & 35.27 & 44.20 & +8.93 \\
Yeast viability & $\%\left(\mathrm{n}^{\circ} / \mathrm{n}^{\circ}\right)$ & 99.3 & 83.90 & -15.4 \\
Yeast biomass (wet wt.) & $\mathrm{g} / 100 \mathrm{~mL}$ broth & 19.19 & 16.84 & -2.35 \\
Yeast biomass (dry wt.) & $\mathrm{g} / 100 \mathrm{~g}$ wet biomass & 26.38 & 24.44 & -1.94 \\
Carbohydrates(TRE+GLY) & $\mathrm{g} / 100 \mathrm{~g}$ drywt. & 15.63 & 0.00 & -15.63 \\
Carbohydrates(TRE+GLY) & $\mathrm{g} / 100 \mathrm{~mL}$ broth & 0.770 & 0.130 & -0.640 \\
Ethanol & $\mathrm{g} / 100 \mathrm{~mL}$ broth & 3.47 & 3.64 & $+0.17(3 \cdot 36)^{*}$ \\
Nitrogen in broth & $\mathrm{g} / 100 \mathrm{~mL}$ broth & 0.13 & 0.19 & $+0.06(1.18)$ \\
Glycerol & $\mathrm{g} / 100 \mathrm{~mL}$ broth & 0.59 & 0.02 & +0.043 \\
\hline SA-1 & & & & +9.53 \\
\hline Yeast protein & $\mathrm{g} / 100 \mathrm{gdrywt}$. & 42.29 & 51.82 & -31.51 \\
Yeast viability & $\%\left(\mathrm{n}^{\circ} / \mathrm{n}^{\circ}\right)$ & 91.33 & 59.82 & -3.43 \\
Yeast biomass (wet wt.) & $\mathrm{g} / 100 \mathrm{~mL}$ broth & 20.40 & 16.97 & -1.56 \\
Yeast biomass (dry wt.) & $\mathrm{g} / 100 \mathrm{~g}$ wet biomass & 25.80 & 24.24 & -17.31 \\
Carbohydrates(TRE+GLY) & $\mathrm{g} / 100 \mathrm{~g}$ drywt. & 24.76 & 7.45 & -1.299 \\
Carbohydrates(TRE+GLY) & $\mathrm{g} / 100 \mathrm{~mL}$ broth & 1.300 & 0.001 & $+0.42(7.98)^{*}$ \\
Ethanol & $\mathrm{g} / 100 \mathrm{~mL}$ broth & 3.07 & 3.49 & $+149(2.83)$ \\
Nitrogen in broth & $\mathrm{g} / 100 \mathrm{~mL}$ broth & 0.063 & 0.213 & +0.032 \\
Glycerol & $\mathrm{g} / 100 \mathrm{~mL}$ broth & 0.277 & 0.309 & \\
\hline
\end{tabular}

*Figures within parenthesis are variations of parameters related to dry cell weight.

Table 3. Trehalose (TRE) and glycogen (GLY) degradation rate constants $\left(\mathrm{h}^{-1}\right)$ for yeast cells incubated at various temperatures.

\begin{tabular}{cccccc}
\hline Yeast & & $38^{\circ} \mathrm{C}$ & $40^{\circ} \mathrm{C}$ & $42^{\circ} \mathrm{C}$ & $44^{\circ} \mathrm{C}$ \\
\cline { 3 - 6 } PE-2 & TRE & 0.0243 & 0.0291 & 0.1580 & 0.2030 \\
& GLY & 0.0412 & 0.0459 & 0.1380 & 0.2650 \\
SA-1 & TRE & 0.0396 & 0.0239 & 0.1670 & 0.2300 \\
& GLY & 0.0360 & 0.0334 & 0.1540 & 0.1500 \\
\hline
\end{tabular}

was observed as the temperature was changed from $40^{\circ} \mathrm{C}$ to $42^{\circ} \mathrm{C}$. The constant degradation rate, at $42^{\circ} \mathrm{C}$ was 5 times as high as at $40^{\circ} \mathrm{C}$. Higher temperatures are not recommended in real practice, since glycogen degradation ceases after 8-12h of incubation at $42^{\circ} \mathrm{C}$ during the fermentation with PE-2 strain. A similar situation was observed after $4-8 \mathrm{~h}$ at $44^{\circ} \mathrm{C}$ during the fermentation with SA-1 strain. These results might indicate that the glycogen-degrading system (debranching and/or phosphorilase) is sensitive at high temperatures (Fig. 2 and 3). Nevertheless, the trehalose degrading system was not affected by higher temperatures $\left(42^{\circ} \mathrm{C}\right.$ or $\left.44^{\circ} \mathrm{C}\right)$.

The Arrhenius plot (14) applied to the degradation rate data at varying degrees of temperature $\left(38^{\circ} \mathrm{C}, 40^{\circ} \mathrm{C}, 42^{\circ} \mathrm{C}, 44^{\circ} \mathrm{C}\right)$ show that the degradation reaction is not linear (Fig. 4). The highest degradation reaction speed was observed at temperatures between $40^{\circ} \mathrm{C}$ and $42^{\circ} \mathrm{C}$ whereas, the degradation speed was lower atlevels of temperature either below or above this interval.

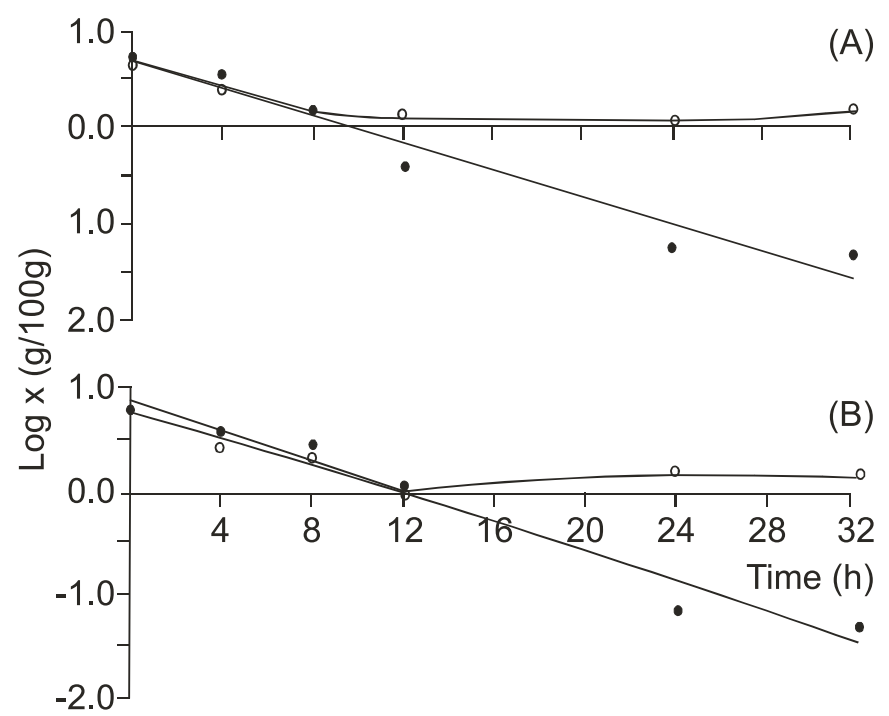

Figura 2. Trehalose $(O)$ and glycogen $(O)$ contents in yeast cells treated at $42^{\circ}$ C. (A) S. cerevisiae PE-2 and (B) S. cerevisiae SA-1.

The activation energy (DE) value calculated between $40^{\circ} \mathrm{C}$ and $42^{\circ} \mathrm{C}\left(165.90\right.$ and $107.94 \mathrm{kcal}^{\circ}{ }^{\circ} \mathrm{K}^{-1} . \mathrm{mol}^{-1}$ for trehalose and glycogen respectively for PE-2 strain, and 190.64 and $149.87 \mathrm{kcal}^{\circ}{ }^{\circ} \mathrm{K}^{-1} . \mathrm{mol}^{-}$ ${ }^{1}$ respectively for SA-1 strain) indicates that these values are above the normal levels of enzymatic reactions, yet they are 


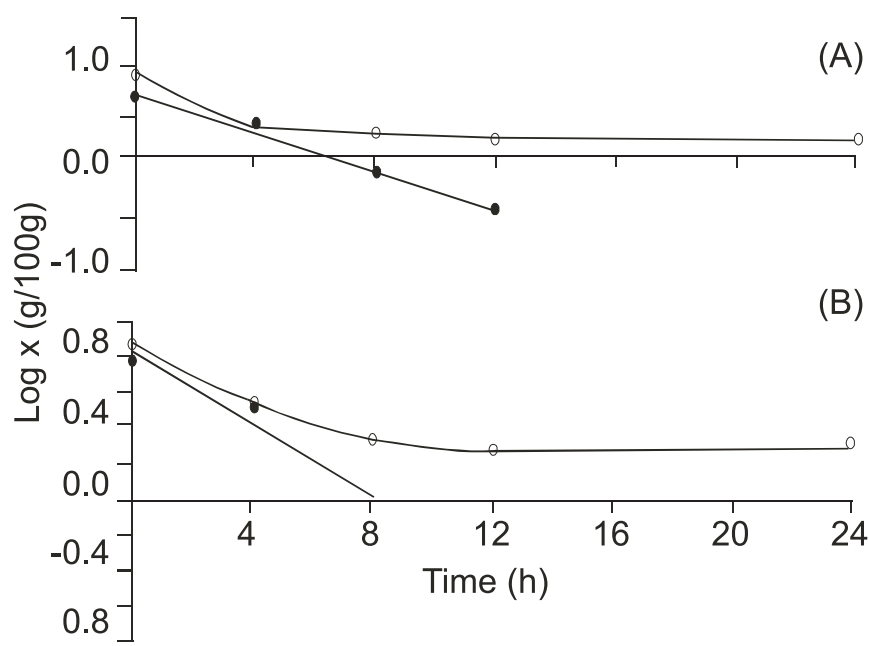

Figura 3. Trehalose $(O)$ and glycogen $(O)$ contents in yeast cells treated at $44^{\circ} \mathrm{C}$. (A) S. cerevisiae PE-2 and (B) S. cerevisiae SA-1.

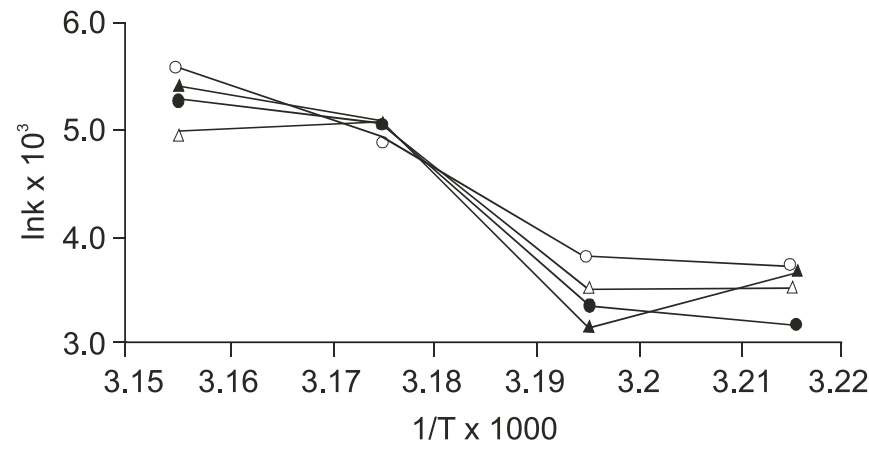

Figura 4. Arrhenius plot of trehalose and glycogen degradation rate $\left(\mathrm{k} \cdot \mathrm{h}^{-1}\right)$ from yeast cells at high temperatures. Trehalose $(\mathbf{O})$ and glycogen $(\mathrm{O})$ from $\mathrm{S}$. cerevisiae PE-2; trehalose (s) and glycogen (D) from $S$. cerevisiae SA-1.

comparable to the deactivation of cell viability at high temperatures (20). This high activation energy is usually associated with complex phenomena like the death of bacterial spores and vegetative cells. Denaturation of bacterial cell species less sensitive to heating, like Acetobacter aceti, showed lower rate of activation energy $\left(25 \mathrm{Kcal} \mathrm{mol}^{-1}\right)$ (16) but yeast cells showed a very high rate $\left(1750 \mathrm{Kcal}_{\mathrm{mol}}{ }^{-1}\right)(6)$.

The trehalose degrading process is carried out by trehalase (22) and the glycogen process by glycogen phosphorilase and debranching enzymes (25). Trehalose synthesis is carried out by trehalose synthetase and trehalose phosphatase while glycogen synthesis is performed by synthetase and branching enzymes. The complexity of this phenomena could be illustrated by fact that both synthesis and degradation processes are somehow stimulated by an increase of temperature $(11,15,18)$. This situation may be responsiblefor the $\mathrm{S}$ shaped curves in Arrhenius plot.

\section{ACKNOWLEDGMENTS}

This work was supported by Fundação de Amparo a Pesquisa do Estado de São paulo (FAPESP) - project no. 1997/ 13805-2 and by the FERMENTEC-SC Ltda.

\section{RESUMO}

\section{Mobilização do glicogênio e trealose endógenos de leveduras industriais}

A fermentação dos carboidratos de reserva, glicogênio e trealose é um procedimento para aumentar o nível de proteína das células de leveduras com simultâneo aumento na produção de etanol. Este trabalho estudou a cinética de degradação do glicogênio e trealose em duas linhagens industriais de Saccharomyces cerevisiae (PE-2 e SA-1), bem como o efeito de diferentes temperaturas $\left(38^{\circ}, 40^{\circ}, 42^{\circ}\right.$ e $\left.44^{\circ} \mathrm{C}\right)$ na velocidade de degradação. A fermentação endógena foi conduzida com suspensão de leveduras a $20 \%$ (m/v) em massa úmida, no vinho com 3 a 4,5\% (v/v) de etanol. A degradação dos carboidratos de reserva, a $40^{\circ} \mathrm{C}$, seguiu uma cinética de primeira ordem, mostrando que sua taxa é dependente da concentração dos carboidratos na célula. A taxa especifica de degradação (k) variou de 0,0387 a $0,0746 h^{-1}$. Em relação a outros parâmetros analisados a $40^{\circ} \mathrm{C}$, foi observado que a viabilidade e biomassa seca e úmida foram reduzidas, enquanto a reserva de proteína celular e etanol, glicerol e nitrogênio no meio aumentaram. A degradação do glicogênio e trealose em diferentes temperaturas $\left(38^{\circ} \mathrm{C}, 40^{\circ} \mathrm{C}\right.$, $42^{\circ} \mathrm{C}$ e $44^{\circ} \mathrm{C}$ ) mostrou que a $38^{\circ} \mathrm{C}$ a taxa de degradação foi a menor, ao passo que a partir de $42^{\circ} \mathrm{C}$ ou superior, a degradação do glicogênio não mais progrediu após poucas horas de incubação. Portanto, do ponto de vista prático, a melhor temperatura de incubação é em torno de $40^{\circ} \mathrm{C}$. A aplicação da equação de Arrheniusmostrou que as energias de ativação de $40^{\circ} \mathrm{C} \mathrm{a} 42^{\circ} \mathrm{C}$ foram 165,90 e $107,94 \mathrm{kcal}^{\circ}{ }^{\circ} \mathrm{K}^{-1} \cdot \mathrm{mol}^{-1}$ para trealose e glicogênio respectivamente para a linhagem PE-2, e 190,64 e $149,87 \mathrm{kcal}^{\circ} \mathrm{K}^{-1} / \mathrm{mol}^{-1}$, para a linhagem SA-1 respectivamente.

Palavras-chave: Saccharomyces cerevisiae, glicogênio, trealose, levedura, fermentação.

\section{REFERENCES}

1. Amorim, H.V.; Basso, L.C. Processo para aumentar os teores alcoólicos do vinho e protéico da levedura após o término da fermentação. Brazlian Pat. P.I., 9:102.738, Jun. 28, 1991. 
2. Andrietta, S.R.; Migliari, P.C.; Andrietta, M.G.S. Classificação das cepas de levedura de processos industriais de fermentação alcoólica utilizando capacidade fermentativa. STAB. Açúcar, Álcool e Subprodutos, 17(5):54-59, 1999.

3. Brin, M. Transketolase: clinical aspects. In: Colowick, S.P.; Kaplan, N.O. (eds.). Methods Enzymology., Academic Press, New York, 9:506514, 1966.

4. Caro, I.; Pérez, I.; Cantero, D. Development of a kinetic model for the alcoholic fermentation of must. Biotechnol. Bioeng., 38:742748, 1991.

5. Copersucar. Seminário sobre produção e comercialização de levedura de cana. Centro de Tecnologia da Copersucar, Piracicaba, SP, Brazil, 1987.

6. Crowe, J.H.; Whittam, A.A.; Chapman, D. Crowe, L.M. Interaction of phospholipid monolayers with carbohydrates. Biochim. Biophys. Acta, 769:151-159, 1984.

7. Dijck, P.V.; Colavizza, D.; Smet, P.; Thevelein, J.M. Differential importance of trehalose in stress resistance in fermenting and nonfermenting Saccharomyces cerevisiae cells. Appl. Environ. Microb., 6(1):109-115, 1995.

8. Herber, W.K.; Robinett, R.S.R. Determination of carbon sources in fermentation media using high-performance anion-exchange liquid chromatography and amperometric detection. J. Chromatogr. A., 676:287-295, 1994.

9. Keller, F.; Schellenberg, M.; Wiemken, A. Localization of trehalose in vacuoles and trehalose in the cytosol of yeast (Saccharomyces cerevisiae). Archiv. Microbiol., 131(1):298-301, 1982.

10. Lillie, S.H.; Pringle, J.R. Reserve carbohydrate metabolism in Saccharomyces cerevisiae: responses to nutrient limitation. J. Bacteriol., 143(3):1384-1394, 1980.

11. Londesborough, J.; Vuorio, O.E. Purification of trehalose synthase from baker's yeast. Its temperature - dependent activation by fructose 6 - phosphate and inhibition by phosphate. Eur. J. Biochem., 216:841-848, 1993.

12. Madigan, M.T.; Martinko, J.M. Parker, J. BROCK Biology of microorganisms. ${ }^{\text {th }}$ Ed. Prentice, Hall, N. Jersey, 1997.
13. Miyada, V.S. A levedura seca na alimentação de suínos. In: Suinucultura. Soc. Bras. Zootec. Piracicaba, Brazil, 39-66, 1990.

14. Moore, W.J. Physical Chemistry. $4^{\text {th }}$ Ed. London, Longmans, 1964, $869 \mathrm{p}$.

15. Neves, M.J.; François, J. On the mechanism by which a heat shock induces trehalose accumulation in Saccharomyces cerevisiae. Biochem. J., 288:859-864, 1992.

16. Ory, I.; Romero, L.E.; Cantero, D. Modelling the kinetics of growth of Acetobacter aceti in discontinous culture: influence of the temperature of operation. Appl. Microbiol. Biotechnol., 49:189193, 1998.

17. Panek, A.D.; Mansure, J.J.C.; Eleutherio, E.C.A. The role of trehalose in yeast cells under stress. Cryobiol., 30:238-239, 1993.

18. Parrou, J.L.; Teste, M.A.; François, J. Effects of various types of stress on the metabolism of reserve carbohydrates in Saccharomyces cerevisiae: genetic evidence for a stress-induced recycling of glycogen and trehalose. Microbiol., 143:1891-1900, 1997.

19. Rocha-Leão, M.H.M.R.; Panek, A.D.; Carvalho, C.V.L.A. Glycogen accumulation during growth of Saccharomyces cerevisiae: catabolite repression effects. IRCS Med. Sci., 12:411-412, 1984.

20. Stambo, C.R. Thermobacteriology in Food Processing. Academic Press, N. York, 1965.

21. Suomalainen, L.; Pfaffli, S. Changes in the carbohydrate reserves of baker's yeast during growth and standing. J. Inst. of Brew., 67:249254, 1961.

22. Thevelein, J.M. Regulation of energy metabolization in fungi. Microbiol. Rev., 48:42-59, 1984.

23. Trevelyan, W.E.; Harrison, J.S. Studies on Yeast Metabolism. 5. The trehalose content of baker's yeast during anaerobic fermentation. Biochem. J., 62(2):177-183, 1956a.

24. Trevelyan, W.E.; Harrison, J.S. Studies on Yeast Metabolism. 7. Yeast carbohydrate fractions. Separation from nucleic acid, analysis, and behavior during anaerobic fermentation. Biochem. J., 63:2333, 1956b.

25. Voet, D.; Voet, J.G. Biochemistry. $2^{\text {th }}$. New York: John Wiley; Sons, 1995. 1360p. 